\title{
Antibacterial and immunomodulatory effect of cell free supernatant of Lactobacillus plantarum against Shigella flexneri
}

\author{
Jyoti Goad, Sushma Bharrhan, Neha Garg, Praveen Rishi \\ Department of Microbiology, Basic Medical Sciences Block, \\ Panjab University, Chandigarh-160014, India
}

\begin{abstract}
Background \& Objectives: Shigellosis is endemic throughout the world causing great deal of morbidity and mortality. Emergence of antibiotic resistance and lack of vaccine against Shigella, necessitates exploitation of alternative strategies to combat Shigella infection. The present study was undertaken to evaluate the effect of cell free supernatant (CFS) from Lactobacillus plantarum (L. plantarum) against Shigella flexneri (S. flexneri).

Methods: The effect of CFS from Lactobacillus plantarum against S. flexneri was studied in terms of agar well diffusion assay, time kill assay, adherence inhibition and macrophage functions.

Results: It was found that CFS inhibits $S$. flexneri as indicated by zone of inhibition and continuous decrease in the $\mathrm{CFU} / \mathrm{ml}$ for 16 hours of incubation period. A decrease in the number of Shigella cells adhering to mouse intestinal cells was also observed in the presence of CFS. Cell free supernatant could significantly decrease the levels of malondialdehyde (MDA) and nitrite. Levels of lactate dehydrogenase (LDH) and Tumor necrosis factor- $\alpha$ (TNF- $\alpha$ ) were almost restored in the presence of CFS. The study revealed correlation between LDH and MDA levels, as well as between nitrite and TNF- $\alpha$ levels suggesting the immunomodulatory effects of CFS in addition to its antibacterial property against Shigella.
\end{abstract}

Interpretation and Conclusions: Regular intake of probiotic food supplements may prove to be beneficial against enteric infections due to sustained release of antimicrobials.

Keywords: Cell free supernatant, Drug resistance, Lactobacillus plantarum, S. flexneri

\section{INTRODUCTION}

Shigellosis is endemic throughout the world causing great deal of morbidity and mortality, especially in developing countries because of improper sanitary conditions. ${ }^{1}$ Recent estimates have fixed the Shigella disease burden at 90 million episodes and 1,08,000 deaths per year. ${ }^{2}$ Antibiotics have been the mainstay of therapy to cure Shigella infections which mainly include fluoroquinolones, azithromycin and extended spectrum cephalosporins. However, reports of emergence of drug resistance have recently indicated that Shigella strains have become resistant to multiple antimicrobial agents. These include

\section{Corresponding Author :}

Dr. (Mrs.) Praveen Rishi, FAMI, FABMS

Professor

Department of Microbiology,

Basic Medical Sciences Block

Panjab University, Chandigarh-160014, INDIA

Email: rishipraveen@yahoo.com initially sulfonamides then tetracycline, chloramphenicol, streptomycin and subsequently ampicillin, kanamycin, trimethoprim and sulfonamide. ${ }^{3}$ At present, only ciprofloxacin is recommended for the treatment of Shigella infection by WHO. However, cases of resistance even against ciprofloxacin have been reported lately which has reduced the options for the safe and effective treatment of Shigella. ${ }^{4}$ Emergence of antibiotic resistance amongst Shigella spp., absence of proper vaccination, high disease rates, as well as the associated side effects of antibiotics necessitates the exploitation of alternative strategies to combat Shigella infection. In this context, the use of probiotics or its cell free supernatant (CFS) as therapeutics against Shigella infections might prove useful, as it would help in avoiding the use of antibiotics thereby decreasing the risk of associated side effects.

Probiotics are defined as "live micro-organisms," which, when administered in adequate amounts confer a health benefit on the host. ${ }^{5}$ Earlier, we have shown the amelioratory potential of probiotics against Salmonella 
infections.${ }^{6,7}$ However, information on the use of probiotics in reference to shigellosis is still scanty. The present study was therefore, designed to assess the antagonistic effects, if any, of cell free supernatant of the probiotic strain against $S$. flexneri.

\section{MATERIAL AND METHODS}

\section{Bacterial strains}

Lactobacillus plantarum (L. plantarum) MTCC 2621 and S. flexneri MTCC 1457 were procured from Institute of Microbial Technology, Chandigarh, India. $L$. plantarum and S. flexneri were grown in De Mann Rogosa Sharpe (MRS) broth and nutrient broth, respectively. The strains used in the study were confirmed by their morphological and biochemical characteristics.

\section{Animals}

Four to five weeks old BALB/c female mice (18-22 g) obtained from Central Animal House, Panjab University, Chandigarh, India were housed under standard conditions with free access to feed and water ad libitum. Throughout the study, the guidelines of the Institutional Animal Ethics Committee, Panjab University, Chandigarh (India) were followed. The experimental protocols were approved by the Institutional Animal Ethics Committee of the Panjab University, Chandigarh, India and performed in accordance with the guidelines of Committee for the Purpose of Control and Supervision of Experiments on Animals (CPCSEA), Government of India, on animal experimentation.

\section{Preparation of CFS from $L$. plantarum}

The CFS was prepared as described by Ogunbanwo et al. ${ }^{8}$ L. plantarum was propagated in MRS broth $(\mathrm{pH}$ 6.5 ) for $24 \mathrm{~h}$ at $37^{\circ} \mathrm{C}$. Cell free supernatant was obtained by centrifugation of the culture at $9000 \mathrm{~g}$ for $20 \mathrm{~min}$ at $4^{\circ} \mathrm{C}$. The supernatant was filtered though $0.22 \mu \mathrm{m}$ pore size cellulose acetate filter.

\section{Agar well diffusion assay (Agar WDA)}

The antibacterial activity of the cell free supernatant prepared was preliminarily checked by slight modification of agar well diffusion assay given by Sarkar and Banerjee. ${ }^{9}$ Soft nutrient agar was seeded with $10^{8}-10^{9}$ colony forming units $/ \mathrm{ml}(\mathrm{CFU} / \mathrm{ml})$ of $S$. flexneri. Wells of $6 \mathrm{~mm}$ diameter were punched in the agar plates and filled with $100 \mu \mathrm{l}$ of CFS. The plates were then incubated at $37^{\circ} \mathrm{C}$ for $18 \mathrm{~h}$ and observed for the zone of inhibition around the wells.

\section{Time kill assay}

Nutrient broth inoculated with $S$. flexneri $\left(10^{8} \mathrm{CFU} / \mathrm{ml}\right)$ was supplemented with $200 \mu \mathrm{l}$ of cell free supernatant and incubated at $37^{\circ} \mathrm{C}$. Samples were drawn and plated at regular intervals of $0 \mathrm{~h}, 4 \mathrm{~h}, 8 \mathrm{~h}, 12 \mathrm{~h}, 16 \mathrm{~h}, 20 \mathrm{~h}$ and $24 \mathrm{~h}$ on nutrient agar plates (in triplicates). The plates were incubated at $37^{\circ} \mathrm{C}$ for $24 \mathrm{~h}$ and colony forming units were calculated.

\section{Adhesion assay}

To determine the inhibitory effect of CFS on adhesion of $S$. flexneri to mouse intestinal epithelial cells, the mouse intestinal cells were isolated by the method described by Booth and Shea. ${ }^{10}$ Viability of the cells was checked by trypan blue and inhibitory effect was evaluated by the method described by Fayol-Messaoudi et al. ${ }^{11}$ Briefly, 1 $\mathrm{ml}$ of phosphate buffer saline (PBS) $(0.1 \mathrm{M}, \mathrm{pH}-7.4)$ containing $10^{8} \mathrm{CFU} / \mathrm{ml}$ of $S$. flexneri was mixed with $1 \mathrm{ml}$ of $10^{6}$ mouse intestinal epithelial cells. These cells were divided into two groups: Group 1: Infected intestinal epithelial cells $\left(10^{6}\right.$ cells/ml $)+$ CFS $(200 \mu 1)$; Group 2: Infected intestinal epithelial cells $\left(10^{6}\right.$ cells $\left./ \mathrm{ml}\right)+$ PBS $(200 \mu 1)$ (served as control). The cells were then incubated for $2 \mathrm{~h}$ at $37^{\circ} \mathrm{C}$ in $5 \% \mathrm{CO}_{2}$ incubator. After the interaction, smears were made on a clean dry glass slide. After air drying smears were fixed with methanol followed by staining with Giemsa stain. The inhibition of adhesion of $S$. flexneri to mouse intestinal epithelial cells was observed under $100 \mathrm{x}$ objective using light microscope.

\section{Isolation and interaction of peritoneal macrophages with $S$. flexneri}

Murine peritoneal macrophages were isolated by the method as described by us earlier. ${ }^{12}$ To assess the effect of $S$. flexneri on macrophage functions, $10^{6}$ macrophages $/ \mathrm{ml}$ were interacted with $S$. flexneri, (at 1:50 as multiplicity of infection). The resulting mixture was divided into two groups: Group 1: Infected macrophages $(500 \mu \mathrm{l})+$ normal saline $(100 \mu \mathrm{l})$; Group 2: Infected macrophages $(500 \mu \mathrm{l})+\mathrm{CFS}(100 \mu \mathrm{l})$. This reaction mixture was incubated at $37^{\circ} \mathrm{C}$ in the presence of $5 \% \mathrm{CO}_{2}$ for $18 \mathrm{~h}$. After incubation, lysis buffer $(20 \mathrm{mM}$ tris $\mathrm{HCl}, 150 \mathrm{mM} \mathrm{NaCl}, 1 \mathrm{mM}$ EDTA, $1 \%$ Triton-X-100, $1 \mathrm{mM}$ PMSF) was added to the reaction mixture in the ratio of $1: 1$, followed by incubation for $20 \mathrm{~min}$ at $4{ }^{\circ} \mathrm{C}$. The mixture was then centrifuged at 200-300 $\mathrm{g}$ for 15 min. The supernatant thus obtained was used to study the following parameters: 


\section{Measurement of lipid peroxidation}

Extent of lipid peroxidation in the culture supernatant of macrophages was evaluated by the method of Wills. ${ }^{13}$ The results were expressed as nanomoles of malondialdehyde (MDA) per milligram of protein, using the molar extinction coefficient of chomophore $(1.56 \times$ $\left.10^{5} \mathrm{M}^{-1} \mathrm{~cm}^{-1}\right)$. Protein content of culture supernatant was calculated according to the method described by Lowry et al..$^{14}$

\section{Measurement of superoxide dismutase (SOD) activity}

SOD activity was determined in the culture supernatant by the method described by Kono. ${ }^{15}$ Change in absorbance was read at $560 \mathrm{~nm}$ for 3 min with 30 seconds interval. SOD activity was expressed as units of SOD per milligram of protein where one unit activity was defined as the amount of SOD required to inhibit the rate of reduction of NBT by $50 \%$.

\section{Measurement of lactate dehydrogenase (LDH) activity}

LDH activity was measured in the culture supernatant of macrophages according to the method of Bergmeyer and Bernt. ${ }^{16}$ The reaction mixture contained $50 \mathrm{mM}$ potassium phosphate buffer $(\mathrm{pH} 7.5), 0.5 \mathrm{mM}$ sodium pyruvate, $0.1 \mathrm{mM} \mathrm{NADH}$ and appropriate amount of phenazine methosulfate in a final volume of $1 \mathrm{ml}$. The reaction was started by addition of NADH and the rate of oxidation of $\mathrm{NADH}$ was measured at $340 \mathrm{~nm}$. One unit of enzyme activity was defined as the amount of enzyme catalyzing oxidation of $1 \mu \mathrm{mol}$ of NADH per minute based on the extinction coefficient of 6.22 $\mathrm{mM}^{-1} \mathrm{~cm}^{-1}$.

\section{Tumor necrosis factor $-\alpha(\mathrm{TNF}-\alpha)$ assay}

TNF- $\alpha$ assay was performed in culture supernatants using ELISA plates precoated with monoclonal antibody for mouse TNF- $\alpha$ (ChemiKine ${ }^{\mathrm{TM}}$ Mouse TNF- $\alpha$ kit) as described by us earlier. ${ }^{17}$ The results were expressed as $\mathrm{pg} / \mathrm{ml}$ of the TNF- $\alpha$ released. The ELISA was sensitive to less than $60 \mathrm{pg} / \mathrm{ml}$ of the TNF- $\alpha$ released.

\section{Nitrite estimation}

Nitrite levels were estimated in the culture supernatant of macrophages by the method of Green et al. ${ }^{18} 100 \mu \mathrm{l}$ of the sample was mixed with $400 \mu \mathrm{l}$ of distilled water and $500 \mu \mathrm{l}$ of Griess reagent and incubated at room temperature for $10 \mathrm{~min}$ (in dark). Absorbance was measured at 546nm. Nitrite was quantified using standard graph of sodium nitrite.

\section{Statistical analysis}

Results were expressed as mean \pm standard deviation (SD). The inter group variation was assessed by one way analysis of variance (ANOVA) followed by Fisher's least significant difference (LSD) test. Statistical significance of the results was calculated to at least $\mathrm{p}$ $<0.05$.

\section{RESULTS}

\section{Agar well-diffusion assay (agar-WDA)}

The agar well diffusion assay (agar-WDA) revealed that CFS from L. plantarum was inhibitory to the growth of $S$. flexneri as evidenced by the zone of growth inhibition

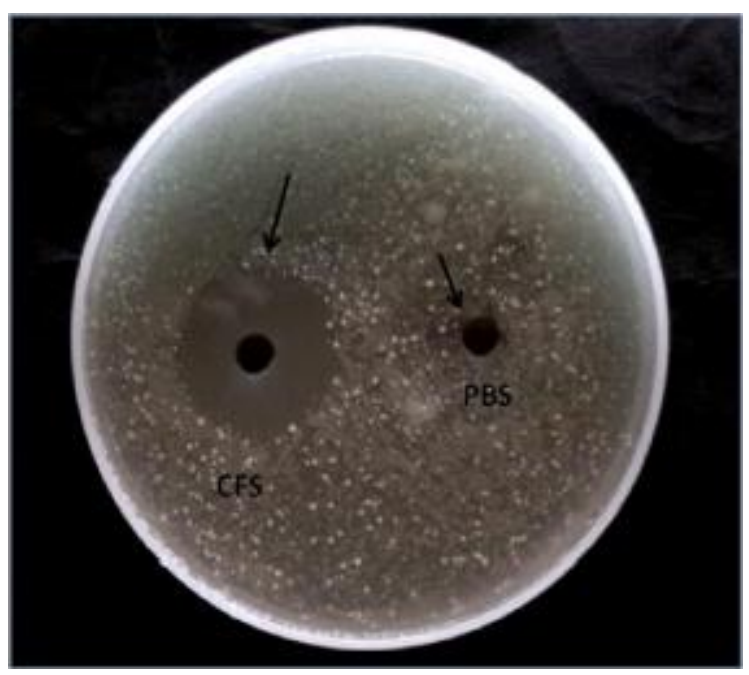

Figure I: Radial well diffusion assay showing zone of inhibition $(11 \mathrm{~mm})$ produced by cell free supernatant against $S$. flexneri

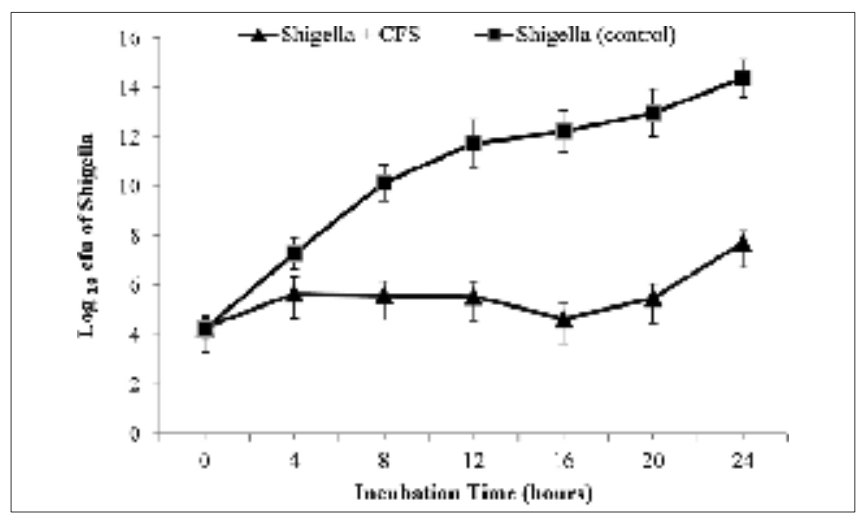

Figure II: $\log _{10}$ CFU/ml of S. flexneri at different time intervals in the presence of CFS 
(11mm diameter) around the wells filled with $100 \mu \mathrm{l}$ of CFS while no zone of inhibition was observed around the control wells (Figure I).

\section{Time kill assay}

To evaluate if CFS has bactericidal or bacteriostatic effect against $S$. flexneri time kill assay was performed at different time intervals. After $4 \mathrm{~h}, 8 \mathrm{~h}, 12 \mathrm{~h}, 16 \mathrm{~h}$ of incubation with CFS, a log unit decrease of 1.62, 4.55, 6.18, and 7.56 units was observed. However, after $16 \mathrm{~h}$ of incubation slight increase was observed in the CFU of Shigella (7.477, 6.65 at 20 and $24 \mathrm{~h}$ respectively) (Figure II).

\section{Adhesion assay}

The study indicated that the numbers of cells adhering to mouse intestinal cells were significantly less in the presence of CFS as compared to those adhered in the absence of CFS (Figure III a, b, c).

\section{MDA levels}

Significantly increased MDA level $(\mathrm{p}<0.01)$ was observed in the culture supernatant of macrophages infected with S. flexneri (350.11 \pm 35.70 nanomoles of $\mathrm{MDA} / \mathrm{mg}$ protein) as compared to that of uninfected macrophages (control, 246.18 \pm 26.60 nanomoles of MDA/mg protein). However, when the macrophages were infected with Shigella in the presence of CFS, a significant decrease in the MDA level was observed $(259.88 \pm 18.40$ nanomoles of MDA/mg protein, $\mathrm{p}<0.05$ ) (Table I).

\section{SOD activity}

SOD activity was observed to be significantly decreased $(\mathrm{p}<0.001)$ when macrophages were infected with Shigella (3.04 \pm 0.61 units/mg protein) as compared to that of uninfected macrophages $(7.17 \pm 1.03$ units $/ \mathrm{mg}$ protein). SOD activity might have been decreased due to the consumption of antioxidants to scavenge the reactive oxygen species (oxidants). However, treatment of infected macrophages with the CFS resulted in a nonsignificant increase in the SOD activity ( $4.18 \pm 0.57$ units/ mg protein) (Figure IV).

\section{Lactate dehydrogenase (LDH) activity}

A significant increase $(\mathrm{p}<0.05)$ was observed in the LDH activity of macrophages infected with Shigella (36.92 \pm $3.8 \mathrm{millimoles} / \mathrm{min} / \mathrm{mg}$ protein) as compared to that of uninfected macrophages $(25.08 \pm 3.52$ millimoles $/ \mathrm{min} /$ mg protein) (Table I). However, significant decrease in the $\mathrm{LDH}$ activity $(27.67 \pm 4.21 \mathrm{millimoles} / \mathrm{min} / \mathrm{mg}$ protein,

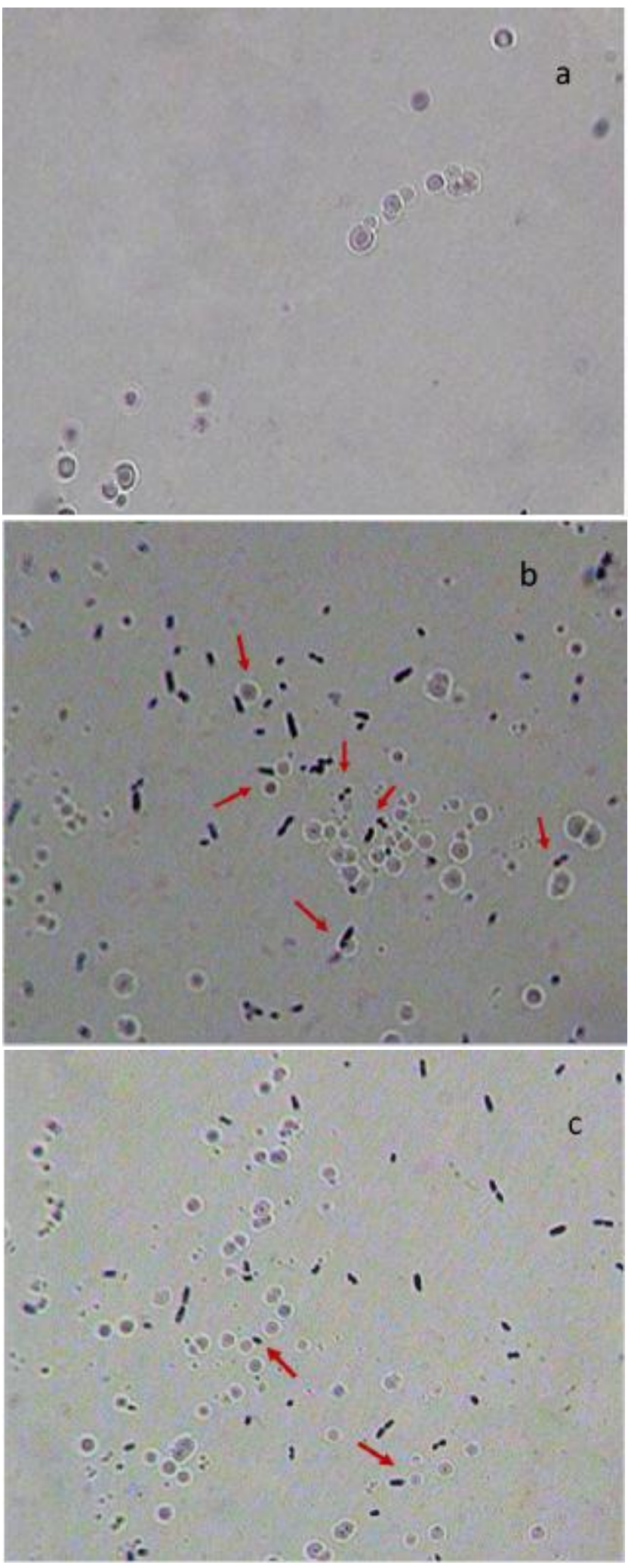

Figure III: Representative photomicrographs of adhesion assay $(1000 X)($ a) Isolated intestinal epithelial cells from BAL B/c mouse (control) (b) Adhesion of S. flexneri to murine intestinal epithelial cells (c) Inhibition of adhesion of S. flexneri to murine intestinal epithelial cells 
Table I

Effect of CFS on macrophage functions

\begin{tabular}{llll}
\hline Groups & $\begin{array}{l}\text { MDA } \\
(\mathrm{nmoles} / \mathrm{mg} \text { protein })\end{array}$ & $\begin{array}{l}\text { LDH } \\
(\mathrm{mmoles} \mathrm{NADH} / \\
\text { min/mg protein })\end{array}$ & Nitrite $(\mu \mathrm{g} / \mathrm{ml})$ \\
\hline Uninfected macrophages & $246.18 \pm 26.60$ & $25.08 \pm 3.52$ & $1.38 \pm 0.49$ \\
Macrophages + S. flexneri & $350.11 \pm 35.70^{*}$ & $36.92 \pm 3.8^{\dagger}$ & $4.05 \pm 1.03^{*}$ \\
Macrophages + S. flexneri + CFS & $259.88 \pm 18.40^{*}$ & $27.67 \pm 4.21^{\#}$ & $1.52 \pm 0.22^{\ddagger}$ \\
\hline
\end{tabular}

"shows significant difference $(" \mathrm{p}<0.01)$ from uninfected macrophages, ${ }^{*}$ shows significant difference $\left({ }^{*} \mathrm{p}<0.05\right)$ from macrophages infected with $S$. flexneri, "shows significant difference ( $\left.{ }^{\dagger} p<0.05\right)$ from uninfected macrophages, ${ }^{*}$ shows significant difference $\left({ }^{\sharp} \mathrm{p}<0.01\right)$ from macrophages infected with S. flexneri.



Figure IV: Estimation of SOD activity of macrophages infected with $S$. flexneri in the absence and presence of CFS. Values are expressed as mean \pm SD of three individual observations. *Shows significant difference (*p<0.05) fromuninfectedmacrophages (control)

$\mathrm{p}<0.05)$ was observed on treatment of infected macrophages with CFS (Table I).

\section{Release of TNF- $\alpha$}

A significant increase $(\mathrm{p}<0.05)$ was observed in the release of TNF- $\alpha$ in the culture supernatant of macrophages infected with Shigella $(208.5 \pm 19.7 \mathrm{pg} /$ $\mathrm{ml}$ ) as compared to that of uninfected macrophages (147.2 $\pm 21.15 \mathrm{pg} / \mathrm{ml}$ ) (Fig. 5). However, on infecting the macrophages in presence of CFS, TNF- $\alpha$ levels were restored to near normal $(153.6 \pm 27.6 \mathrm{pg} / \mathrm{ml}, \mathrm{p}<0.05)$ (Figure $\mathrm{V})$.

\section{Nitrite levels}

Significant increase $(\mathrm{p}<0.01)$ in the nitrite levels was observed in the culture supernatant of macrophages infected with $S$. flexneri $(4.05 \pm 1.03 \mu \mathrm{g} / \mathrm{ml})$ as compared to that of uninfected macrophages $(1.38 \pm 0.49 \mu \mathrm{g} / \mathrm{ml})$. However, on infecting the macrophages in presence of

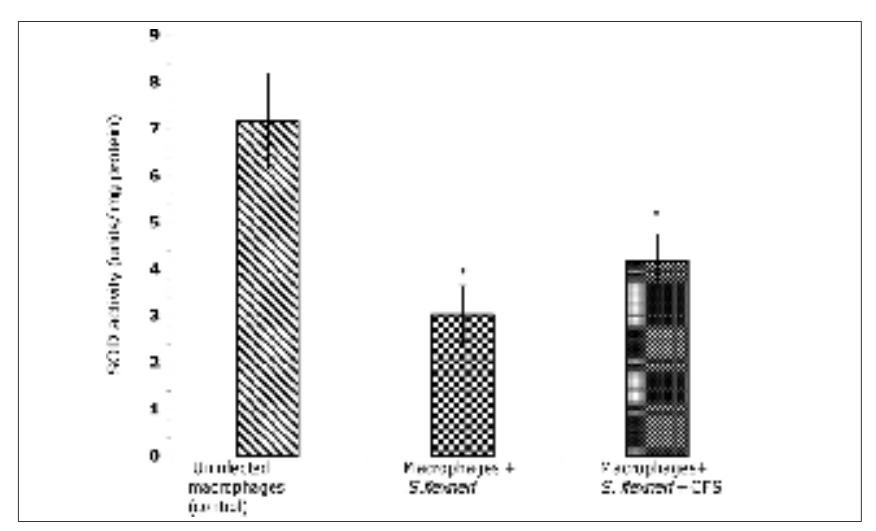

Figure V: Effect of CFS on the levels of $T N F-\mathrm{a}$ released by macrophages when infected with Shigella. Values are expressed as mean $\pm S D$ of three individual observations. *Shows significant difference (*p<0.05) from uninfected macrophages (control). \# Shows significant difference (\#p<0.05) frommacrophages infected withSh.flexneri.

CFS, a significant decrease $(\mathrm{p}<0.01)$ in the nitrite levels $(1.52 \pm 0.22 \mu \mathrm{g} / \mathrm{ml})$ was observed (Table I).

\section{DISCUSSION}

The emergence and dissemination of multidrug-resistant strains of Shigella as well as the non-availability of an anti-Shigella vaccine poses to be a serious global threat. This provides impetus to the efforts to identify and explore alternative strategies to combat Shigella infections. Keeping this in view, we evaluated the effect of CFS from $L$. plantarum against $S$. flexneri.

It has been suggested that the CFS from Lactobacillus contains several antibacterials including bacteriocins, hydrogen peroxide, lactic acid and non lactic acids which enable to kill or inhibit the growth of pathogens. ${ }^{19,20}$ Therefore, the anti-Shigella activity of CFS (evidenced by radial diffusion assay) might be 
attributed to the presence of all these antibacterial effector molecules in the cell free extract of L. plantarum. However, the observations from the time kill assay indicate that CFS has a bacteriostatic effect on Shigella upto $16 \mathrm{~h}$ of incubation after which an increase in CFU was observed. It may be hypothesized that the action of CFS after $16 \mathrm{~h}$ might have been neutralized by the metabolic end products produced by the $S$. flexneri strain.

Probiotics can protect the intestine by competing with pathogens for attachment, strengthening tight junctions between enterocytes and enhancing the mucosal immune response to pathogens. ${ }^{21}$ In the present study also, a decrease in the number of Shigella cells adhering to mouse intestinal cells was observed in the presence of L. plantarum CFS. L. plantarum has been demonstrated to have the ability to protect against enteropathogenic E. coli (EPEC) induced damage of the epithelial monolayer barrier function by preventing changes in host cell morphology, attaching/effacing (A/E) lesion formation, monolayer resistance, and macromolecular permeability. ${ }^{22-24}$ It appears that antimicrobial factors present in the CFS might be having inhibitory effect on ligand-receptor interactions. In this context, it has been reported that the phenomenon of adherence inhibition may involve not only competition for eukaryotic cell receptors but also an action of antimicrobial substances produced by lactic acid bacteria. ${ }^{25}$ Additionally, probiotics may also promote mucous secretion to enhance intestinal barrier function.

Lipid peroxidation is the process of oxidative degradation of polyunsaturated fatty acids (PUFAs) which is a feature of many types of cell injury in which free radical intermediates are produced in excess. ${ }^{26} \mathrm{~A}$ measure of LPO products such as malondialdehyde (MDA) is an indication of the extent of peroxidation and thus cell damage. Significant decrease in the MDA levels was seen in presence of CFS, indicating the decrease in cell damage in the presence of CFS. Corroborating with our results, it has been shown that pretreatment with L. rhamnosus and L. acidophilus leads to decrease in extent of lipid peroxidation in rat intestine infected with S. dysenteriae.${ }^{27}$ Further supporting our data, it has been reported that intact cells and intracellular cell-free extracts of $L$. acidophilus have a very good antioxidative effect in inhibiting linoleic acid peroxidation and scavenging the 1, 1-diphenyl-2-picryl hydrazl radical. ${ }^{28}$

The development of tissue injury and the outcome of the disease depend upon the balance between the generation of toxic radicals and tissue antioxidant status. ${ }^{29}$ A non significant increase in SOD activity was seen in the presence of CFS. In agreement with our results, it has been shown that metabolites of L. acidophilus and Bifidobacterium inhibited ileal ulcer formation and lipid peroxidation in rats treated with a non-steroidal anti-inflammatory drug, 5-bromo-2-(4-fluorophenyl)-3(4-methylsulfonylphenyl) thiophen. ${ }^{30}$ The increased SOD activity together with decreased MDA levels, as observed in the present study, indicate that CFS obtained from L. plantarum may offer protection against Shigella infection due to its antioxidative property. Moreover, the decreased levels of LDH in the culture supernatants of treated macrophages may be correlated to the reduced extent of lipid peroxidation in presence of CFS, thus validating that CFS decreases the extent of cell damage during the Shigella infection.

TNF- $\alpha$ is a proinflammatory cytokine which is released during Shigella infection along with other proinflammatory cytokines like IL-1, IL-6 and plays a major role in epithelial destruction in experimental shigellosis. ${ }^{31}$ In the present study, a significant increase was observed in the release of TNF- $\alpha$ in the culture supernatant of macrophages infected with Shigella. However, on infecting the macrophages in the presence of CFS, a significant decrease in the TNF- $\alpha$ levels was observed. Corroborating with our data, it has been documented that TNF- $\alpha$ mRNA synthesis increased in HT-29 cells infected with Shigella causing acute intestinal inflammation through the production of inflammatory cytokines. ${ }^{32}$ It has also been reported that cells pretreated with a combination of $L$. rhamnosus and $L$. acidophilus followed by Shigella infection showed minimal TNF- $\alpha$ expression, substantiating the protective effect. ${ }^{27}$ This decrease in the TNF- $\alpha$ levels might be helpful in reducing the severity of inflammation.

Nitric oxide (NO) is an important signalling molecule which acts on many tissues to regulate diverse range of physiological processes. The estimation of nitrite is an indirect measure of nitric oxide content. In the present study, increased nitrite levels after infection with Shigella correlated well with the incresed TNF- $\alpha$ levels. The increased nitrite levels might be associated with TNF- $\alpha$ (as has been observed in the present study) as it is known for its potent stimulatory activity of iNOS which increases the NO levels. On the contrary, decrease in nitrite levels was observed in the presence of CFS. The observed 
decrease in nitrite levels may be attributed to the ability of probiotics to attenuate TNF- $\alpha$ or TNF- $\alpha$ stimulated IL- 8 production which might have decreased the NO levels. ${ }^{33,34}$

The above studies indicate that cell free supernatant from $L$. plantarum has antibacterial and immunomodulatory effects against S.flexneri. Owing to the antiShigella and anti-Salmonella activity (as evidenced from earlier study in our lab $^{7}$ ) of CFS from L. plantarum, it may be exploited as an antibacterial agent against enteric pathogens. Regular intake of probiotic food supplements may prove to be beneficial in enteric infections due to sustained release of antimicrobials over a longer period of time. Furthermore, supplementation of probiotics along with prebiotics may prove to be more meaningful for the posterior gastrointestinal pathology such as shigellosis.

\section{Conflict of interest}

The authors declare that they have no conflict of interest

\section{REFERENCES}

1. Niyogi SK. Shigellosis. J Microbiol 2005;43:133-43.

2. World Health Organization. Diarrhoeal diseases, 2009. http:// www.who.int/mediacentre/factsheets/fs330/en/index.html. Accessed 26 September 2011.

3. Pickering LK. Antimicrobial resistance among enteric pathogens. Semin Pediatr Infect Dis 2004;15:71-7.

4. World Health Organization. Antimicrobial resistance, 2011. http:/ /www.who.int/mediacentre/factsheets/fs194/en/. Accessed 26 September 2011.

5. FAO/WHO. Food and Agriculture Organization of the United Nations, WHO, 2011. http://www.who.int/entity/foodsafety/ publications/fs_management/en/probiotics.pdf. Accessed 18 August 2011.

6. Rishi P, Kaur S, Bhalla MPS, Preet S, Tiwari RP. Selection of probiotic Lactobacillus acidophilus and its prophylactic activity against murine Salmonellosis. Int J Pro Pre 2008;3: 89-98.

7. Rishi P, Preet S, Kaur P. Effect of L. plantarum cell-free extract and co-trimoxazole against Salmonella Typhimurium: a possible adjunct therapy. Ann Clin Microbiol Antimicrob 2011;10:9.

8. Ogunbanwo ST, Sanni AI, Onilude AA. Characterization of bacteriocin produced by Lactobacillus plantarum $\mathrm{F} 1$ and Lactobacillus brevis OG1. Afr J Biotechnol 2003;2:219-27.

9. Sarkar PK, Banerjee SK. Antibacterial activity of lactic acid bacterial isolates obtained from the natural habitats. J Food Sci Technol 1996;33:231-3.

10. Booth C, O'Shea JA. Isolation and culture of intestinal epithelial cells. In: Freshney RI, Freshney MG, editors. Culture of epithelial cells, $2^{\text {nd }}$ ed. New York: John Wiley \& Sons Inc; 2002. p. 303-35.
11. Fayol-Messaoudi D, Berger CN, Coconnier-Polter MH, LievenLe VM, Servin AL. pH-, lactic acid-, and non-lactic aciddependent activities of probiotic Lactobacilli against Salmonella enterica serovar Typhimurium. Appl Environ Microbiol 2005;71(10):6008-13.

12. Chander H, Majumdar S, Sapru S, Rishi P. Macrophage cell death due to Salmonella enterica serovar Typhi and its acid stress protein has features of apoptosis. Microbiol Immunol 2005;49(4):323-30.

13. Wills ED. Mechanisms of lipid peroxide formation in animal tissues. Biochem J 1966;99(3):667-76.

14. Lowry OH, Rosebrough NJ, Farr AL, Randall RJ. Protein measurement with Folin phenol reagent. J Biol Chem 1951;193(1):265-75

15. Kono Y. Generation of superoxide radical during autoxidation of hydroxylamine and an assay of superoxide dismutase. Arch Biochem Biophys 1978;186(1):189-95.

16. Bergmeyer HU, Bernt E. Lactate dehydrogenase UV-assay with pyruvate and NADH. In: H. U. Bergmeyer editor. Methods of Enzymatic Analysis. New York, NY: Academic Press; 1974. p. 574-8.

17. Rishi P, Kaur H, Tirkey N, Chopra K, Bharrhan S, Chanana V, et al. Are the increases in local tumor necrosis factor and lipid peroxidation observed in pre-starved mice infected with Salmonella Typhimurium markers of increased liver damage? Microbes Infect 2006;8(7):1695-701.

18. Green LC, Wagner DA, Glogowski J, Skipper PL, Wishnok JS, Tannenbaum SR. Analysis of nitrate, nitrite and [15N] nitrate in biological fluids. Anal Biochem 1982;126(1):131-8.

19. Stiles ME, Hastings JW. Bacteriocin production by lactic acid bacteria: potential for use in meat preservation. Trends Food Sci Technol 1991;2:247-51.

20. Klaenhammer TR. Genetics of bacteriocins produced by lactic acid bacteria. FEMS Microbiol Rev 1993;12(1-3):39-86.

21. $\mathrm{Lu} \mathrm{L}$, Walker WA. Pathologic and physiologic interactions of bacteria with the gastrointestinal epithelium. Am J Clin Nutr 2001;73(6):1124S-30S.

22. Hirano J, Yoshida T, Sugiyama T, Koide N, Mori I, Yokochi T. The effect of Lactobacillus rhamnosus on enterohemorrhagic Escherichia coli infection of human intestinal cells in vitro. Microbiol Immunol 2003;47(6):405-9.

23. Parassol N, Freitas M, Thoreux K, Dalmasso G, Bourdet-Sicard R, Rampal P. Lactobacillus casei DN-114001 inhibits the increase in paracellular permeability of enteropathogenic Escherichia coli-infected T84 cells. Res Microbiol 2005;156(2):256-62.

24. Sherman PM, Johnson-Henry KC, Yeung HP, Ngo PS, Goulet J, Tompkins TA. Probiotics reduce enterohemorrhagic Escherichia coli $\mathrm{O} 157: \mathrm{H} 7$ - and enteropathogenic E. coli O127:H6-induced changes in polarized T84 epithelial cell monolayers by reducing bacterial adhesion and cytoskeletal rearrangements. Infect Immun 2005;73(8):5183-8.

25. Jankowska A, Laubitz D, Antushevich H, Zabielski R, Grzesiuk E. Competition of Lactobacillus paracasei with Salmonella enterica for adhesion to Caco-2 cells. J Biomed Biotechnol 2008;357964.doi: 10.1155/2008/357964 
26. Slater TF. Free-radical mechanisms in tissue injury. Biochem J 1984;222(1):1-15.

27. Moorthy G, Murali MR, Devaraj SN. Protective role of lactobacilli in Shigella dysenteriae 1-induced diarrhea in rats. Nutrition 2007;23(5):424-33.

28. Lin MY, Yen CL. Antioxidative ability of lactic acid bacteria. J Agric Food Chem 1999;47(4):1460-6.

29. Winrow VR, Winyard PG, Morris CJ, Blake DR. Free radicals in inflammation: second messengers and mediators of tissue destruction. Br Med Bull 1993;49(3):506-22.

30. Kinouchi T, Kataoka K, Bing SR, Nakayama H, Uejima M, Shimono K, et al. Culture supernatants of Lactobacillus acidophilus and Bifidobacterium adolescentis repress ileal ulcer formation in rats treated with nonsteroidal antiinflammatory drug by suppressing unbalanced growth of aerobic bacteria and lipid peroxidation. Microbiol Immunol 1998;42(5): $347-55$.
31. Moorthy G, Murli MR, Devaraj SN. Lactobacilli inhibit Shigella dysenteriae 1 induced pro-inflammatory response and cytotoxicity in host cells via impediment of Shigella-host interactions. Dig Liver Dis 2010;42(1):33-9.

32. Jung HC, Eckmann L, Yang SK, Panja A, Fierer J, MorzyckaWroblewska E, et al. A distinct array of proinflammatory cytokines is expressed in human colon epithelial cells in response to bacterial invasion. J Clin Invest 1995;95:55-65.

33. Gopal PK, Prasad J, Smart J, Gill HS. In vitro adherence properties of Lactobacillus rhamnosus DR20 and Bifidobacterium lactis DR10 strains and their antagonistic activity against an enterotoxigenic Escherichia coli. Int J Food Microbiol 2001;67(3):207-16.

34. Madsen K, Cornish A, Soper P, McKaigney C, Jijon H, Yachimec $\mathrm{C}$, et al. Probiotic bacteria enhance murine and human intestinal epithelial barrier function. Gastroenterology 2001;121(3): 580-91. 